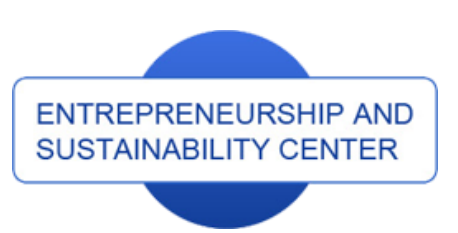

Publisher

http://jssidoi.org/esc/home

\section{enterprise}

europe

network

Business Support on Your Doorstep

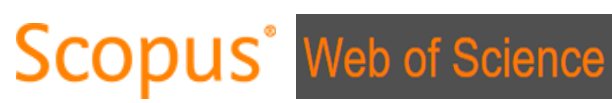

\title{
EGYPT BEYOND COVID 19, THE BEST AND THE WORST-CASE SCENARIOS*
}

\author{
Mohamed Ramadan A. Rezk ${ }^{1}$, Leonardo Piccinetti ${ }^{2 *}$, Amr Radwan ${ }^{3}$, Nahed M. Salem ${ }^{4}$, \\ Mahmoud M. Sakr ${ }^{5}$, Anas Khasawneh ${ }^{6}$ \\ 1,3,4,5 Academy of Scientific Research and Technology (ASRT), 101 Elkasr Alini St, 11516, Cairo, Egypt \\ ${ }^{2,6}$ Europe for Business Ltd, Warrington, United Kingdom
}

\begin{abstract}
E-mails: ${ }^{1}$ mramadan79@gmail.com, ${ }^{2 *}$ l.piccinetti@e4business.eu (Corresponding author); ${ }^{3}$ radwan.amro@gmail.com; ${ }^{4}$ nahedelashkar.astt@gmail.com; ${ }^{5}$ msakr@asrt.sci.eg; ${ }^{6}$ anas.efb@gmail.com
\end{abstract}

Received 10 July 2020; accepted 18 November 2020; published 30 December 2020

\begin{abstract}
The Coronavirus SARS-CoV-2 (COVID-19) pandemic caused a global substantial effect whilst affecting local healthcare systems and productive sectors among many others. It was a "wake up call" for the economy (investors), policymakers (governments) and the entire society. Progressively, it became widely obvious there is no "going back to normal" and a new normal will gradually be in place. Many questions were raised in this uncertainty situation including how this new normal will affect productive sectors? How can countries leverage the new realities forced on them by COVID-19 to shape better future plans or to achieve their pre-identified goals efficiently? In the middle of this global chaos, are their opportunities for developing economies? This paper tries to answer these questions with specific emphasis on Egypt using foresighting tools while highlighting the best-case and worst-case scenarios for Egypt in the post-COVID-19 world.
\end{abstract}

Keywords: COVID-19; impact, economy; policymakers; society; scenarious, Egypt

Reference to this paper should be made as follows: Rezk, M.R.A., Piccinetti, L., Radwan, A., Salem, N.M., Sakr, M.M., Khasawneh, A. 2020. Egypt beyond COVID 19, the best and the worst-case scenarios. Entrepreneurship and Sustainability Issues, 8(2), $147-162$. http://doi.org/10.9770/jesi.2020.8.2(9)

Jel Codes: O10, O11

* This work received support from TED-PPP project, an EU funded project with agreement number ENI 2017/394-139
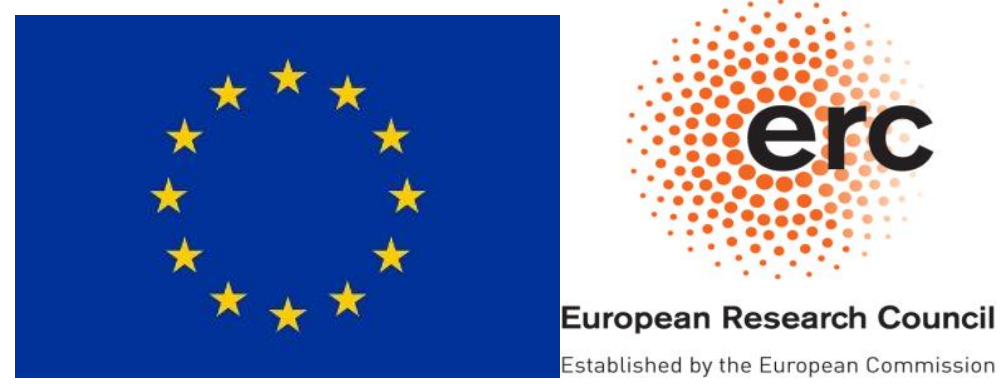


\section{ENTREPRENEURSHIP AND SUSTAINABILITY ISSUES}

ISSN 2345-0282 (online) http://jssidoi.org/jesi/

2020 Volume 8 Number 2 (December)

http://doi.org/10.9770/jesi.2020.8.2(9)

\section{Introduction}

By beginning of December 2019, several cases of pneumonia of unknown etiology were reported in Wuhan, Hubei province, China (Huang $\mathrm{C}$ et al., 2020). This was later officially named coronavirus disease 2019 (COVID19) by the World Health Organization (WHO). Very quickly, COVID-19 had been classified as a global pandemic. As of May 21, 2020, COVID-19 pandemic has affected about 5 million people and claimed over 328,471 deaths globally (Johns Hopkins, 2020).

The rapid spread of COVID-19 has basically halted the global economy. It has inflicted high, and rising, human costs worldwide given that that the necessary protection measures severely impacted economic activity. This had severe impact on the livelihoods of many millions of people especially in economies with large percentages of daily wage earners. As a result of the pandemic, the global economy is projected to contract sharply by $3 \%$ in 2020. (World Economic Outlook, 2020). While scientists are feverishly seeking vaccines and cures, policymakers are desperately working to implement market, monetary and financial measures targeting the market to support locally affected families and companies. The health, economic, social, and political impact of this pandemic have changed the world as we know it and will push everyone to re-evaluate their priorities and build new alliances.

COVID-19 has already had a severe impact on the health system, scientific research, food energy environment, financial, tourism, sports as well religious practices. Impact has been by and large negative but, in every field, there appears to be new opportunities opening from this negative starting point for the post-COVID world.

In education, most countries closed schools, colleges, and universities to reduce contact and save lives. Teaching, like many businesses, moved online, on an untested and unprecedented scale. Many student assessments also moved online while others were forced into using project work for assessment, with a lot of trial and error and uncertainty for everyone (Simon \& Hans, 2020). However, on the positive side, it has been a great transformation leading to popularization of the use of technology in education that can lead to a complete revaluation of the modes of learning and assessment.

As countries went into lockdown, most industrial activities shut down globally including commercial aerospace, travel, apparel, luxury, automotive industries, and insurance. The crisis has also amplified existing challenges by millions of workers all over the world who are facing the prospect of losing their jobs (Abhijit et al,2020). However, it has also catapulted the idea of work for home and will lead to a transformation of the work culture.

Transport is one of the most hard-hit sectors due to lockdown. Road and air transport came to a halt as people were not allowed or hesitated to travel. According to official reports, air travel dropped by $96 \%$ due to COVID19: the lowest in 75 years (CNN, 2020). COVID-19 will require a complete transformation of the airline business. It will surely force people to reconsider their mode of transportation and result in a total transformation of airline and tourism industry. Egypt, like the rest of the world, closed airports and restricted travel excluding only the return of Egyptians from abroad.

While COVID-19 has had a severe negative impact on human lives and the global economy, it has had an unexpected positive impact on the environment and climate change and sustainability. Air pollution levels have dropped significantly due to limited social and economic activities (Dutheil et al., 2020). NASA Satellite images of the northeastern part of United States, showed that CO2 emission concentration in March 2020 dropped by up to 30\% due to lockdown, compared to March 2015 to 2019 (NASA, 2020). This unexpected positive change alongside the realization of the fragility of our civilization has restored the belief that indeed, something can and 


\section{ENTREPRENEURSHIP AND SUSTAINABILITY ISSUES}

ISSN 2345-0282 (online) http://jssidoi.org/jesi/ 2020 Volume 8 Number 2 (December) http://doi.org/10.9770/jesi.2020.8.2(9)

must be done about global warming replacing the sense of inevitability that was prevailing before COVID-19. There is no question that the COVID-19 experience will energize the drive for the protection of the environment in the post COVID world.

In the recent years, the world saw a rise in nationalism and isolationist policies pushing for individualism in dealing with global challenges like climate change for example. COVID-19 was a grim reminder that the best of health care systems and strongest economies are not a protection from pandemics and what hit one country, quickly resonated around the world. Most nations quickly learned that fighting the pandemic requires collaboration amongst medical experts to find cure and vaccine as fast as possible. Coronavirus CAN represent an opportunity to review how humanity can work together beyond national boundaries to face common challenges. (Mohamed and Dunya, 2020).

Based on all the above we argue that while COVID's massive disruption of the world order as we know it has been devastating, it presents the possibility of a fresh starting point for the world. There is no "going back to normal". The world will establish "a new normal". Countries who attempt to simply return to business as usual face serious negative consequences as the world is no longer what it was. Those who will emerge successfully from the COVID-19 devastation are the ones who recognize that the governing rules, constraints, and opportunities have completely changed, and everything must be reassessed. This necessitates new foresighting exercise to envision the plausible scenarios for the future depending on how the world reacts to the new drivers shaping the post-COVID-19. The question is what will that new normal be?

Since the start of foresighting with Shell Corporation in the energy sector, its use has spread widely. Governments and corporations have conducted foresight studies to better plan technology-related investments (Reger, 2001), to prepare for potential bioterrorism attacks, and to envision the impact of global warming.

Foresight goes hand in hand with future studies and is closely associated with scenario-building (IPTS, http://forlearn.jrc.ec.europa.eu/index.htm). Recently, we saw more reliance on future studies to prepare for the future (Rezk, et al, 2019). The purpose of a foresight project is as much for helping today's decision-making as it is for creating awareness about tomorrow's challenges and opportunities through building detailed scenarios of alternative plausible futures along with what must be in place to make them happen.

Scenario planning is an increasingly applied strategic process in a variety of contexts (Amer, Daim, \& Jetter, 2013; Chermack, 2017; Varum \& Melo, 2010). Because of the applied nature of scenario planning, it has grown into a standard practice for most organizations and many countries (Amer, Daim, \& Jetter, 2013; Varum \& Melo, 2010). Recently, many scenarios were developed for the world post COVID-19 (Mohamed and Dunya, 2020). Most have focused on the "health aspects" with the driving factors being the discovery of vaccines. Many others developed scenarios based on the economy rebounding very slowly, fast or intermittently as a result of the vaccine availability. The recovery effort would require several strategies. Looking at the pre-COVID-19 environment, it is clear that momentum has already increased around the need for a framework reset; several leading companies have stepped up and invested in this revolutionary direction, while innovative government agencies have put forward significant legislative initiatives to allow the transition. (Jocelyn Blériot, 2020).

This paper presents a foresighting exercise to provide alternatives for the future of Egypt in this new postCOVID-19 global context through best case and worst case scenarios intended to help politicians capture the emerging post COVID-19 opportunities and shape a future that was difficult to envision before COVID-19.

We assume that a vaccine is available, and the health aspects of the crisis are under control. The paper focuses on a select set of areas to highlight the opportunities to build a better post corona world and the huge losses if these opportunities are not captured. 


\section{Methodology}

In this paper, we follow the standard approach of writing two archetypes scenarios (Hunt et al., 2012): the best case scenario and worst case scenario. We start with defining the key drivers that affect the future of Egypt through the perspective of specific selected sectors. The scenarios are built by interlinked interaction among these drivers. Both scenarios start from assumptions of availability of vaccines and reasonable economic recovery.

\subsection{Defining Key Drivers of Uncertainty}

We start with identifying the drivers shaping the future to construct the best and worst scenarios. In this context, the drivers are classified into internal and external drivers that could influence the future of selected sectors (Table 1). The listed drivers incorporate national and international trends for the world after COVID-19.

Table 1. Internal and External drivers for Egypt in the post COVID-19 world

\begin{tabular}{|l|l|}
\hline \multicolumn{1}{|c|}{ Internal drivers } & \multicolumn{1}{|c|}{ External drivers } \\
\hline National political leadership action & Changes in world leadership \\
Centralization of services and state control & Global collaboration on global challenges \\
State surveillance & Geopolitics \\
Culture and social attitudes & Globalism vs nationalism \\
Social, economic and development priorities & Global priorities \\
Social cohesion & Freedom of movement \\
Focus on public health and healthcare & Interest in tourism \\
Technological innovation and R\&D investment & Investments, external funds, \\
Information and communication infrastructure & Diversification of sources/supply chains \\
Scale of technology adoption & Technological innovation \\
Digitalization of services & Data protection/sharing globally \\
Data protection & Workforce culture, automation \\
Workforce culture & Efficiency vs resilience \\
Institutional agility to cope with the dynamic changes and & Economic recovery \\
uncertainty & Vaccine availability \\
& \\
Economic recovery & \\
Vaccine availability & \\
& \\
\hline
\end{tabular}

\subsection{Building of Archetypes Scenarios}

Most scenarios already available on the international scene focus on alternative plausible futures for the world depending on early availability of vaccines versus late availability, on virus mutation and on no availability of vaccines or alternative scenarios based on economic assumptions and focused on economic recovery (Deloitte, 2020).

In this paper, the best case scenario (The rainbow after the rain) describes the future if everything lined up perfectly while the worst case scenarios (When the sun never rose again) describes the future if no effort was made to leverage the opportunities created by COVID-19 and Egypt continues business as usual where it left off before Corona as the world moves to the new normal Drivers are incorporated in each scenario. 


\section{ENTREPRENEURSHIP AND SUSTAINABILITY ISSUES}

ISSN 2345-0282 (online) http://jssidoi.org/jesi/ 2020 Volume 8 Number 2 (December) http://doi.org/10.9770/jesi.2020.8.2(9)

\section{Results and discussion}

In this paper, we assume that a vaccine will be available on a wide scale by the end of the year and that the economy will be recovering at a reasonable rate. Our focus is on capturing the opportunities in this post-COVID19 world as a direct consequence of the transformations that were never before imaginable while focusing on Egypt as a case study. Capturing these opportunities might inform future strategies and policymaking processes to design actions and interventions that better suit the new realities. Ignoring these opportunities and returning to "normal" in a world that is no longer "normal" might not just miss opportunities but rather result in significant deterioration and negative impact on existing plans. The scenarios focus on a select number of fields as examples to drive the idea of capturing post COVID-19 opportunities. Next level would be a more detailed analysis by experts in each field.

\subsection{Best Case Scenario "The rainbow after the rain"}

When Covid-19 hit, it brought the world to almost a standstill. Hospitals were overwhelmed, and people were dying. Those who were not sick were terrified of becoming infected. Borders around the world were closed. Air traffic came near to a complete shutdown. Universities, schools and factories shut down across the globe. Oil and gas consumption and their price crashed. Stores, gyms, restaurants and businesses closed. People were laid off, and stock markets plunged.

However, at the same time, wars slowed down. Pollution decreased in clearly visible ways. Nature started healing itself. People started getting together to help one another. Poorer countries were helping rich countries. People discovered online technologies could achieve that much in personal and professional communication as well as education. Families started spending more time physically together. A new world was born with a new order and new rules for a new normal. The world recognized that its complete dependence on China for all its manufactured products was a fundamental mistake that endangered lives of millions of people around the world. This was an essential reminder of the necessity of diversifying sources of essential commodities. Governments were reminded of the vital importance of investing in health and a new reality of "working from home" was suddenly the norm.

The Egyptian government was quick to understand that there is no going back to the world before Covid- 19 . While ministries focused on dealing with the pandemic to stop its spread amongst Egyptians, the government coordinated several thinktanks to plan for the new realities post -Covid-19 based on the lessons learned across nations. Work started on best positioning of Egypt for the world post-Corona even before the pandemic was under control (IDSC, 2020).

\subsubsection{Health}

COVID-19 shock resulted in a complete re-evaluation of priorities. Public health is now a top priority from both a medical and an economic perspective when it was realized that stopping the spread of a disease is a much more effective strategy than dealing with the resulting morbidity. The economic value of public health is now a critical parameter in government decisions. Massive campaigns have been initiated to instil the culture of prevention of disease, healthy eating and living. People became much more receptive to such messaging when they realized that the majority COVID-19 deaths occurred in people with pre-existing chronic diseases. Smoking, high consumption of sugar and saturated fats became socially frowned upon, and consumption dropped significantly. Walking and cycling are now the more practical choices, especially that new cities had better planning for bikers and walkers. Sidewalks are clear of coffee shops ad other obstacles and Egyptians have since adopted a lifestyle that includes exercise as a preventative health measure. The government reassessed its food rations to the 


\section{ENTREPRENEURSHIP AND SUSTAINABILITY ISSUES}

ISSN 2345-0282 (online) http://jssidoi.org/jesi/ 2020 Volume 8 Number 2 (December) http://doi.org/10.9770/jesi.2020.8.2(9)

vulnerable groups to ensure their nutritious value and additional taxes were imposed on "junk food" to further discourage their consumption. Egyptians instinctively understood the risk of the multiplying effect of chronic diseases, like diabetes and hypertension, on their exposure to death and are now much more health conscious.

Covid-19 taught the world a huge lesson about the importance of prevention of infection in hospitals and protection of hospital staff and other patients. Following the pandemic, the Egyptian government continued to impose a strict culture of infection control across its hospitals with the full support of healthcare workers who understood clearly that this is for their safety not just that of the patients. Infection control governing healthcare professionals working across hospitals are strictly now in place to stop the infection transmission.

The threat caused by pre-existing health conditions and the importance of knowing what they are to determine the COVID-19 treatment resulted in a major push for personalized medicine. As part of the health insurance system that was being introduced in stages, Egypt now has a personal electronic file for every public insurance patient accessible from every public health provider. This ensures a far much better health care system. It is also driving a national database for all patients.

During the extended period of partial lockdown, many physicians closed their clinics severely limiting access to healthcare while patients hesitated a lot before seeking healthcare except for real emergencies. Meanwhile, other doctors came together and volunteered to offer free general online advice. This was extremely welcomed by many and was the beginning of the transformation. Now, many physicians have online group presence through which they provide basic simple medical advice to patients at much reduced prices but allowing quick access to professionals for the simple cases that may not need physical presence. This was the catalyst that opened the door to todays' world of telemedicine serving remote areas as well as basic needs.

COVID-19 also raised the issue of cleanliness and disinfection across the country as the armed forces scrambled to disinfect buildings and streets. Sanitation and disinfection of all public places is now a standard required procedure post-COVID-19.

Waste collectors are now issued gloves for their safety as well as tools to allow them to clean the sites without exposing them to disease effectively. The whole idea of the virus surviving on surfaces required a severe reevaluation of the safety of the food supply in Egypt, mainly food sold on the street. On a related issue, what happened during the peak of COVID-19 with people hording any medicine or vitamin rumoured to be useful in its treatment has driven the Egyptian Ministry of Health to reconsider public access to medication without a doctor's prescription. While the current system still does allow some access without a prescription to simple medications in recognition of the reality in Egypt, the list of restricted medications has been greatly expanded to break the culture of unnecessary consumption or hording of medicine.

Most importantly, today in Egypt National Security now includes Health Security at the same level of importance as food security and water security. This includes having a national stockpile of medicine and critical hospital equipment to cover the nation for a set number of months just as there is a nationwide inventory of food and water. This also includes a stockpile of raw materials needed for local manufacturing of strategic health security products.

\subsubsection{Industry}

On the industry side, the world reassessed its past focus on efficiency. Resilience, self sufficiency or at least diversification of sources in the supply chain became the new priority. It was clear that as the world scrambles to diversify its sources for products and to break its now-dangerous dependence on China, opportunities will open for countries centrally located like Egypt to step in and be an important node in the newly established network of manufacturing hubs. Egypt's location, central to both Europe and Africa gave it a natural advantage. This 


\section{ENTREPRENEURSHIP AND SUSTAINABILITY ISSUES}

ISSN 2345-0282 (online) http://jssidoi.org/jesi/ 2020 Volume 8 Number 2 (December) http://doi.org/10.9770/jesi.2020.8.2(9)

opportunity was made more likely to turn into reality as Chinese businesspeople were keen to ensure they retain their market share and as such, were quite interested in opening up factories for their products outside of China. This started with announcements for SAMSUNG in late May about expanding their facilities and product line being manufactured in Egypt. Many other industry giants quickly followed suit. The government did exceptional effort to facilitate their entry into Egypt resulting in a huge boost to Egyptian industry. Made in Egypt is now a trusted brand across Middle East, Africa, and Europe (Daily news Egypt, 2020).

COVID-19, as well as the government action to attract Chinese and other manufacturers to Egypt, did not just push the industry forward, but it had a transformative impact on scientific research and innovation. While the Covid-19 crisis pushed local innovators to produce face protectors, respirators, and applications to help in tracing contacts, one factor was critical in driving applied research in Egypt. The government required all factories opening up in Egypt to invest a small percentage of their profit on research and development of their products in Egypt through the collaboration of the Egyptian branch of their business with their other branches and with Egyptian researchers. This had a transformative impact driving applied research in Egypt and leading other industries to do the same. As a result, Egypt is now a global competitor in many products not just manufactured in Egypt but also designed in Egypt.

\subsubsection{Education}

When it came to Education, the abrupt closure of schools and universities thrust everyone into the world of online learning. In Egypt, private schools moved into it instantaneously which was not surprising, but the big surprise was that the public-school system followed very soon after. Given that the ministry was pushing hard in that direction against significant opposition of the change, the Covid-19 imposed closure was a massive boost to the Ministry's efforts. It was an incredible moment of transformation that was seized to drive a complete overhaul of pre-university education at a pace never dreamt of. COVID also forced the acceptance of projects as an evaluation tool in public schools. This was a transformative cultural change that was maintained later as a critical component of the evaluation leading to the current education system. Egypt now has a system that expects and supports independent learning of its students and assesses them on their ability to learn as opposed what was the norm of assessing them on the basis of what they memorized. The transformation that people assumed would take 12 years to complete starting from Grade 1 is now in place after barely two years. COVID-19 eliminated the opposition and opened the way for what is now looked at as a historic transformation.

University education was settled in traditional learning modes and was not as ready to integrate online delivery as pre-university education was. Professors had to arrange for their online delivery in their own independent ways and to choose means of assessment to end the first term in 2020 (except for final years). However, the Supreme Council of Universities acted fast during the summer of 2020 to build on this dramatic change that happened in both university and pe-university education. A high-level committee was put together to explore ways of improving the quality of learning using this technological experience developed so quickly during the pandemic as well as accepted means of assessing learning. When classes returned in Fall 2020, there was no going back, and Egyptian universities had developed a blended learning model where technology is used extensively to invite global experts in live sessions, students learned independently and the lecture time is used for more in-depth discussions, case studies or working out examples. In a word, the classroom is now "inverted" and the learning is "blended". Course evaluation systematically included independent research projects as well as video presentations. In short, the pandemic resulted in breaking all the barriers that slowed down the inevitable transformation in university education and opened up massive opportunities for independent, high-quality blended learning where the teachers became mentors guiding the learning process and students were expected to "learn to learn" by researching the material themselves. 


\section{ENTREPRENEURSHIP AND SUSTAINABILITY ISSUES}

ISSN 2345-0282 (online) http://jssidoi.org/jesi/ 2020 Volume 8 Number 2 (December) http://doi.org/10.9770/jesi.2020.8.2(9)

\subsubsection{Workplace Culture}

Amongst the traditions destroyed by COVID-19, workplace culture was right at the top. Hundreds of millions around the world were forced to work from home conducting the most massive experiment to assess the good and the bad of such experience. The government in Egypt quickly imposed a stay at home or work from home ruling for its employees except those designated as essential workers. The value of existing online government services was obvious. Banks advertised new ways to complete transactions online. Phone companies provided incentives for using online services. Just as the fear of technology in education was broken, it was also broken in work cultures in private companies as well as the government.

Following COVID-19 many government departments realized the value of allowing employees to work from home. Work from home is now accepted with the added transformative benefit that employees are now assessed based on productivity and not on attendance.

The reduction in the capacity of government workers during the quarantine time highlighted the excess employment in government services. Many of these services continued with those designated as "essential". This caused a significant re-evaluation of the number of employees needed in each department. Attractive severance packages were offered to people to retire/resign and many took them up. In some areas with excess capacity and limited work options, employees were given choices of reduced work week with proportional cutback in salary. This option was welcomed by many lower middle-class women eager to spend time at home.

At the same time, the government opened the door for redistribution of workers where they may be required, with necessary retraining. The government also announced a competition for new initiatives. Those proposing new initiatives were allowed to take a leave from their positions to lead the realization of their initiatives and to recruit others from within the government labour force. This resulted in a complete "reimagination" of government and utilization of its extra capacity to provide expanded more friendly services with minimal overhead.

Currently, the government has moved much more aggressively to drive the painfully slowly moving egovernment as citizens were significantly more willing to adapt now that they are more comfortable with technology and more fearful of crowded places. This change has been instrumental not only in modernizing the workforce and services but in curtailing corruption across government and streamlining its services.

The private sector was even more innovative in its approach embracing work from home were possible and establishing the blended week principle where employees worked from home 3 days a week and had to come in only two days a week.

A side benefit this dramatic change in workplace culture and in university/school education had was a really positive unexpected impact on the environment through reducing transportation to and from work while it significantly improved family ties as people now have grown to expect/demand family time.

\subsubsection{Informal sector}

A significant component of daily wage earners was no longer able to get any employment opportunity as the quarantine was established. The government was swift to recognize the need to provide emergency financial support for them. This highlighted the absence of economic sustainability for a large segment of Egyptian society. As a result, the government put in place a "Pensions for all" initiative to allow daily workers to contribute to a small pension fund with generous interest rates provided the funds are not withdrawn before the age of 60 . Participation in this fund also made these wage earners eligible for emergency government assistance in times of need. This initiative was welcomed by over a million people. It started a shift amongst Egyptians to a culture of 


\section{ENTREPRENEURSHIP AND SUSTAINABILITY ISSUES}

ISSN 2345-0282 (online) http://jssidoi.org/jesi/ 2020 Volume 8 Number 2 (December) http://doi.org/10.9770/jesi.2020.8.2(9)

planning for the future rather than living day-to-day and then needing complete government assistance in old age. Those who chose to participate in pension planning were included in a database that was used by companies to search for skilled workers. Workers were rated by their employers which improved their opportunities of being hired by other companies in permanent positions.

On the social level, the system put in place during quarantine led to the respect of specific working hours for stores and coffee shops as well as significant improvements in "social order" in using lineups for example at busy stores. The government succeeded in maintaining these limits on store hours after the quarantine was lifted, resulting in a significant reduction in electricity consumption and more importantly increased family time.

\subsubsection{Environment}

COVID-19 brought the world to a crawl. It was almost like nature was fed up with the excessive pollution in the world and was tired of global warming and decided to force a stop. This temporary stop in industrial activities and transportation showed clear evidence of nature being able to heal itself much faster than was believed possible just prior to COVOD-19. The ozone layer fixed itself, and the hole of the arctic has closed! By the end of April, the quality of air in Egypt improved by 40\%. (CAMS, 2020)

This resulted in a renewed resolve globally to protect the environment as we push for sustainable development. Here in Egypt, driven by an increased awareness of the social and economic value of public health, this caused a significant overhaul of the system of enforcement of environmental controls in all sectors. It also strengthened the government's resolve to decrease Egypt's dependence on fossil fuels and increase the percentage of renewable energy produced and waste. Laws were passed to ensure new cities were designed to require solar energy production and minimize energy consumption and to rely more on public transportation. Pre-university education ensured children understood the importance of caring for the environment, and university education challenged students to come up with environmental innovations that can be manufactured locally. Special funding was made available for changes that can improve compliance with environmental regulations.

\subsection{Worst Case Scenario "When the sun never rose again",}

When COVID-19 hit, it brought the world to almost a standstill. Hospitals were overwhelmed. People were dying. Those who were not sick were terrified of becoming infected. Borders around the world were closed. Air traffic came near to a complete shutdown. Universities, schools, and factories shut down across the globe. Oil and gas consumption and their price crashed. Stores, gyms, restaurants, and businesses closed. People were laid off, and stock markets plunged. Divorce rates increased as families were forced to spend more time together than they ever did and there was a marked increase in domestic abuse. Unemployment skyrocketed, businesses declared bankruptcies and the world was turned upside down. Suddenly, the western countries regarded as invincible were extremely vulnerable and unable to protect the lives of their people or protect their ability to work and earn a living. Third world countries, whose health acre systems were fragile to start with, were left to fend for themselves against the virus and the culture of the people that made its spread much more likely and its treatment a lot less likely to be successful. The geopolitical scene changed dramatically and globalization, which was once an opportunity, was now seen as a threat to both global economy and global health.

A new world was born with a new order and new rules for a new normal. And Egypt was not ready for the change.

The Egyptian government was overwhelmed by the immediate health and economic devastating impact of COVID-19. As it worked on minimizing loss of life and restoring the economy back on the positive track it was following, the terrorism threat remained a top priority requiring significant attention and investment. At the same 


\section{ENTREPRENEURSHIP AND SUSTAINABILITY ISSUES}

ISSN 2345-0282 (online) http://jssidoi.org/jesi/ 2020 Volume 8 Number 2 (December) http://doi.org/10.9770/jesi.2020.8.2(9)

time, retaining the state of social rest in the face of internal forces itching for reasons to recreate uprisings was always the overriding constraint. This limited the government willingness to take drastic actions needed for long term growth in this new world and forced a strategy of "avoidance" of change that may create unrest. Once the spread of the virus was somewhat under control, the government was completely focused on going back to the where things were before Covid-19, resuming its original plans with a lot less resources and avoiding any changes that may upset citizens already under significant economic hardship.

\subsubsection{Health}

The government of Egypt took on the treatment of all COVID-19 case at the government expense. This was a massive unexpected cost at a difficult time when the government trying to rebuild the country's infrastructure, provide social security to its most marginalized, create job opportunities, ensure security, reimagine education and other ambitious projects. It was also coupled with a complete stop in tourism revenue and massive drop in remittances from Egyptians abroad. This huge health cost drain on the already battered budget ended up adversely affecting future investment in the health sector that was had already used up funds originally targeted to other areas.

This was complicated by the fact that Egypt fared much better than ever expected regarding number of deaths compared to western countries of similar size. No scientific explanation existed or was sought as to why Egypt and Africa in general was not as devastated as was initially assumed. Instead, many "theories" have existed and were tacitly accepted about certain vaccinations, the weather, pollution, diet, genes and others. At the end, it was the general belief of most Egyptians that "God takes care of Egypt and will always do". In a very strange way, surviving a huge scale COVID-19 devastation resulted in a belief in "natural immunity" and more disregard for public health, sanitation, food safety or healthy lifestyles on both the individual and government sides. After initially arguing "we must work hard to not repeat the Italian scenario", the prevailing belief was "The Italian scenario can never be repeated here" and people's relaxed attitude towards public health, infection control and other issues became even more relaxed. Given that the government made no effort to understand the reasons behind the relatively limited devastation in Egypt, they made little effort to correct this dangerous public perception.

As the harsh economic environment post COVID-19 reality settled in, the government, keen on avoiding social unrest, was quick to increase the food rations for the marginalized. However, it was unwilling to risk upsetting people by using the opportunity to introduce healthier food options and continued the tradition of including more of "sugar and oil" ensuring the continued unhealthy diet for most needy Egyptians and as such the continued spread of chronic diseases like Diabetes. Such diseases are now so common that they have become accepted as unavoidable part of life. Patients of such diseases continue to overload the system making it impossible to improve the quality of heath care especially given the reduced post-COVID investment in health. Egypt was solidly in a closed cycle of poor public health and nutrition leading to more sick people draining the system more leaving it unable to address long term issues of public health, nutrition or healthy lifestyles.

This deterioration of health care services was exasperated by doctors raising their fees in an effort to make up for lost revenue in the time of Corona and as usual, such increased fees were never later reduced leaving many patients unable to access basic health care. The online medical services that sprouted during COVID-19 continued in a completely unregulated form resulting in significant medical malpractice preying on people unable to access doctors because of their very high fees.

While at one point before COVID, Egypt had started to move slowly towards transformation of its health care system, COVID totally derailed the plans and Egypt is now in much worse shape that it was before. 


\section{ENTREPRENEURSHIP AND SUSTAINABILITY ISSUES}

ISSN 2345-0282 (online) http://jssidoi.org/jesi/

2020 Volume 8 Number 2 (December)

http://doi.org/10.9770/jesi.2020.8.2(9)

\subsubsection{Industry}

Prior to COVID-19, the Egyptian government had long term plans for reviving Egyptian industry. As soon as there was some control on the virus, the government went back to continue where it left off focusing on the exact same areas in its efforts to revive local industry. However, the world had changed. The Egyptian economy like all economies was hit hard and the government had limited resources to invest. It was also much harder to attract foreign investment as the markets had changed dramatically with the world's focus on diversifying from China's hold on manufacturing and the original plans of Egypt did not fit the investors new goals. While investors were keen on investing in areas that help Europe and Africa reduce their dependency on China, Egypt continues pushing its predetermined areas for investment. Investors chose to go where they can address the new needs of the market leaving Egypt empty handed.

While efforts to push local production continue, these are simple incremental efforts that seem ineffective as the world has rearranged its manufacturing priorities. Jordan, Morocco and Alegria captured the opportunities for industrial growth in ways they never could have captured had they been competing with Egypt.

Factories can barely stay operational and need significant government support. They are focused on local market which is not sufficient to allow for growth and to create enough jobs. Unemployment is at unprecedented high levels and foreign currency is at unprecedented low levels resulting in difficulties in importing raw material and consequently further complicating life for industry.

Given that industry is suffering greatly, there is no interest in supporting scientific research and not even product development as businesses go back to survival mode as in post 2011. Egypt's competitiveness continues to deteriorate and as it becomes harder to attract investors or market products, industry's interest in innovation or even development continues to dwindle as businesses are preoccupied with daily challenges. The field of innovation and entrepreneurship which was on a high growth rate track is now practically non-existent.

\subsubsection{Education}

It seemed the pre-university education sector was the most prepared to handle the COVID-19 crisis of school closing given that the ministry was pushing hard for technology-assisted learning prior to Corona. While indeed, the whole system switched to using online education tools, this transformation did not last long, and the ministry was not able to capture the spirit of the change imposed on the system. Teachers refused to accept change to blended learning and worked to disrupt the system. Parents tired of home schooling were unable to appreciate the importance of independent learning or value of projects in place of exams. They were convinced they had more control on results of exams based on memorization. Private tutors eager to re-establish their business and convinced they make higher profit through in person classes managed to re-establish their hold on the learning market. Even private schools were eager to return to normal" to justify their higher fees. While they all acted independently, they were all united in opposition. The government was too concerned about the social unrest that might erupt by antagonizing such broad sectors of society and they caved in. As quickly as everyone turned to online education, everyone turned back to business as usual with the ministry succeeding in only incrementally moving for expanded use of technology aids to learning and reform of learning objectives. This resulted in the waste of significant funds invested in technology as teachers and parents kept pressuring for old fashioned learning resulting in Egypt continuing to fail its young people by not preparing them for the new world were independent learning using technology had become the norm. Egyptian graduates are now further back on world ranking than they ever were making university education even harder and reducing Egyptian graduates' chances of competing regionally and internationally. 


\section{ENTREPRENEURSHIP AND SUSTAINABILITY ISSUES}

ISSN 2345-0282 (online) http://jssidoi.org/jesi/ 2020 Volume 8 Number 2 (December) http://doi.org/10.9770/jesi.2020.8.2(9)

University education was already settled in traditional learning modes and was not as ready to integrate online delivery as pre-university education was. While professors did manage to find online ways to finish the year and based their assessment on group projects, everyone was very eager to go back to their comfort zone as the new academic year started. The Supreme Council of Universities was relieved that the crisis was over and went back "to normal" seeing no reason to change. Students were very anxious about evaluation systems requiring them to learn independently and while they complained about spoon feeding, they quickly realized they can study easier and guarantee grades better in such a system.

Today, as the world moved on to adopt independent learning on a previously unimaginable scale, Egyptian universities continue in "teaching" rather than creating an environment for "independent learning". Students continue to "study for the exam" to maximize grades with no interest in actual learning. The learning environment continues to be based on memorization and as such does not sustain any innovation or creativity. The world that technology opens for learning remains foreign to most Egyptian graduates impacting not only their university learning but their ability to continue learning after graduation.

This has had a very negative impact of the Egyptian workforce as that resistance to technology in education spilled into the workplace. It also had a severe impact of the competitiveness of the Egyptian graduate abroad. Egypt is no longer a key source of advanced skills regionally. This inability to compete regionally left all graduates looking for jobs at home and not finding much. Unemployment has skyrocketed and entrepreneurship disappeared. With a government keen on avoiding social unrest, this resulted in increased support for poverty as opposed to long term initiatives to create employment to break the poverty cycle.

\subsubsection{Workplace Culture}

COVID-19 forced a sudden and almost complete stay at home/work from home rule on government and private businesses. There was considerable hope for a complete overhaul of the government workforce post COVID-19 to determine who is deemed essential and who can continue to work from home reducing traffic and crowding and allowing more efficiency. However, to allow people to work from home, there had to be a mechanism that measures performance based on productivity as opposed to simply physical attendance. There was a brief attempt to put such a system in place but given the massive opposition developed to it, it was dropped. People who were used to attendance being fundamentally the main work requirement were too concerned about productivity assessment and how it will be applied. They realized it will require more work from them and may indicate that they are dispensable and in principle did not trust its fairness. The opposition was very strong and the work required for a complete new assessment system was significant enough that the government ended up dropping the proposal, again to avoid potential unrest caused by 6 million disgruntled government employees and their families. Work culture went "back to normal".

However, as a consequence of the success to block renewal of the workplace, those opposing change were energized to further slow down the already slow progress of e-government. All hopes for use of e-government to stop corruption by separating the user from the employee faded. As the world moved on to a complete overhaul of services and went online facilitating access and making corruption basically impossible; Egypt ended up with a strengthened traditional workforce and more deeply rooted every day corruption. This caused significant frustration to Egyptian citizens fuelling their sense of helplessness and anger at the government seeding discontent and at the same time requiring other government concessions to avoid unrest.

On the private sector side, work-from-home culture continued for a while on a hesitant basis. While the companies tried to make it the norm wherever possible, the overall social culture was very resistant to change and work from home continues to be the exception. 


\section{ENTREPRENEURSHIP AND SUSTAINABILITY ISSUES}

ISSN 2345-0282 (online) http://jssidoi.org/jesi/ 2020 Volume 8 Number 2 (December) http://doi.org/10.9770/jesi.2020.8.2(9)

\subsubsection{Informal sector}

After the hit taken by the informal sector, the focus was on returning these daily wage earners to earning their living. The fact that the government and the civil society and generous individuals stepped in to help removed the urgency of long-term planning. The government focused on creating temporary jobs for this class of workers and the focus of workers was on restoring their ability to earn enough daily. This kept a large segment of society living in a very vulnerable state and continued the culture of dependence on the government as the saviour. Indeed, the quick intervention of the government in case of COVID-19 raised the expectations for future interventions. The assumption now is that in times of economic difficulty, the government must step in and if it did not, social unrest will result. This added a sizeable drain on the economy specifically given that there is no way of verifying whose income was really affected and whose income was not. The size of the informal sector is so huge that abuse of government support for those in need is quite easy and again, hesitation to block abusers in fear of social unrest resulted in significant waste of government funds. The newly developed sense of dependence of the informal sector on government coupled with energized forces opposing change in government, education and other areas lead to a paralyzed government that chose to go back to the concept of general subsidy for everyone to avoid social unrest. That was a massive blow to the structural economic changes the government had been working on successfully pre-COVID-19.

On the social level, following the hours of operation limitations imposed during the quarantine; there was a pentup interest in socializing for both operators of cafes and restaurants and their customers resulting in total chaos in times of operations as well as illegal use of street space for offering services. Streets of Egypt and the big cities became more like slum cities with cafes and street vendors popping up on every street and street corner and taking over sidewalks. The police were totally drained in policing quarantine and as such after quarantine was lifted, they turned a blind eye to violations allowing exponential growth. This drove pedestrians to simply move to the streets competing with cars, slowing down traffic and causing more accidents. Despite the significant investments to restore Egypt's grandeur and impose rules and structure on the streets pre-COVID-19, Egypt's major cities are now more like slums and the government gave up on applying its own regulations.

\subsubsection{Environment}

When the COVID-19 pandemic hit, it was expected that it would ravage through Africa specifically given the density of population, the widespread existence of chronic conditions and the poor state of healthcare compared to western countries. However, it soon became apparent that reality was the exact opposite. While of course there was a significant impact economically as well as in terms of deaths and load on healthcare systems, Africa in general and Egypt survived with relatively lower number of deaths. As scientists worked on understanding what happened, all kinds of social media theories spread. In particular, one theory that gained credibility was a combination of religious belief that God was looking out for Egyptians in particular and that the pollution in the air is what weakened the virus and slowed down its spread. While this was never an official position, it led to a strengthened culture of inaction on environment and tacit belief that pollution is not so bad after all.

As the world moved aggressively towards retaining and driving the improvement in environment brought about by the COVID shutdown, Egypt moved in the opposite direction opening its doors to "dirty industry" as a desperate attempt to create jobs. The quality of air in Egypt is now recognized internationally as one of the worst. This has had an added devastating effect on tourism and tourists who were now more health conscious avoided travelling to Egypt as well as on the health of Egyptians overwhelming a sector that is barely keeping up. 


\section{ENTREPRENEURSHIP AND SUSTAINABILITY ISSUES}

ISSN 2345-0282 (online) http://jssidoi.org/jesi/ 2020 Volume 8 Number 2 (December) http://doi.org/10.9770/jesi.2020.8.2(9)

\section{Recommendations:}

A. Political leadership accept the principle of there being no "normal" to go back to. A new world order is in place now.

B. Fast and quick action based on freedom from past assumptions about what can work and what cannot work and preparedness to control forces trying to go back to business as usual.

C. Government, businesses, NGOs and citizens identify and capture the new opportunities created by the world's determination to ensure resilience rather than efficiency.

D. Government, businesses, NGOs and citizens identify and capture the new opportunities created after established cultural norms have been decimated during quarantine.

\section{Conclusions}

COVID-19 has certainly been a wake-up moment for the world. Some countries understood the "no going back to normal" reality while others were exhausted fighting COVID-19 that they barely had enough energy to go back to the old normal; and they were doomed. In this paper, we present best- and worst-case scenarios for the case of Egypt hoping these scenarios would alert decision makers to the incredible opportunities Egypt has in a post COVID-19 world and the disaster that will follow if these opportunities are missed.

\section{References}

Amer, M., Daim, T. U., \& Jetter, A. 2013. A review of scenario planning. Futures, 46, 23-40. https://doi.org/10.1016/j.futures.2012.10.003

Blériot, J. 2020. The COVID-19 recovery requires a resilient circular economy, International Institutions \& Governments, Ellen MacArthur Foundation https://medium.com/circulatenews/the-covid-19-recovery-requires-a-resilient-circular-economy-e385a3690037

Buheji, M., Ahmed, D. 2020. Foresight of Coronavirus (COVID-19) Opportunities for a Better World. American Journal of Economics, 10(2), 97-108, https://doi.org/10.5923/j.economics.20201002.05

CAMS, European Centre for Medium-Range Weather Forecasts. April 2020. https://atmosphere.copernicus.eu/cams-tracks-recordbreaking-arctic-ozone-hole

Chermack, T.J. (2017). Foundations of Scenario Planning: The Story of Pierre Wack. Routledge. https://www.taylorfrancis.com/books/9781315641232

CNN, 2020. https://edition.cnn.com/2020/04/09/politics/airline-passengers-decline/index.html

Daily news Egypt. 2020. www.dailynewssegypt.com/2020/06/03/samsung-to-invest-84m-over-5-years-in-egyptian-market/

Deloitte. 2020. The world remade by COVID-19, Planning Scenarios for resilient leaders, (https://www2.deloitte.com)

Dutheil, F., Baker, S.J., Navel, V., 2020. COVID-19 as a factor influencing air pollution? Environmental Pollution https://doi.org/10.1016/i.envpol.2020.114466

Hopkins, J. Track Reported Cases of COVID-19 Coronavirus Resource Center, (2020) https://coronavirus.jhu.edu/

Huang. C., Wang, Y., Li, X., Ren, L., Zhao, J., Hu, Y. et al. 2020. Clinical features of patients infected with 2019 novel coronavirus in 


\section{ENTREPRENEURSHIP AND SUSTAINABILITY ISSUES}

ISSN 2345-0282 (online) http://jssidoi.org/jesi/

2020 Volume 8 Number 2 (December)

http://doi.org/10.9770/jesi.2020.8.2(9)

Wuhan, China. The Lancet, 395(10223), 497-506. https://doi.org/10.1016/S0140-6736(20)30183-5

IDSC, Restarting the economy, June 2020, Volume 2 https://www.idsc.gov.eg/IDSC/DocumentLibrary/View.aspx?id=4102

IPTS (is one of the scientific institutes of the European Commission's Joint Research Centre, JRC), http://forlearn.jrc.ec.europa.eu/index.htm

Mitra, A., Chaudhuri, T.R., Mitra, A., Pramanick, P., Zaman, S. 2020. Impact of COVID-19 related shutdown on atmospheric carbon dioxide level in the city of Kolkata. Parana Journal of Science and Education (PJSE), 6(3), 84-92. ISSN: 2447-6153.

NASA, 2020. https://earthobservatory.nasa.gov/images

Rezk, M. R., Radwan, A., Salem, N. M., Sakr, M. M., Tvaronavičienė, M. 2019. Foresight for sustainable energy policy in Egypt: results from a Delphi survey. Insights into Regional Development, 1(4), 357-369. https://doi.org/10.9770/ird.2019.1.4(6)

\section{Acknowledgements}

Acknowledgement is due to Dr Tyseer Aboulnasr, O.ONT, FCAE, FEIC, P.Eng. for her contributions to the scenario writeup. This work received support from TED-PPP project, an EU funded project with agreement number ENI 2017/394-139
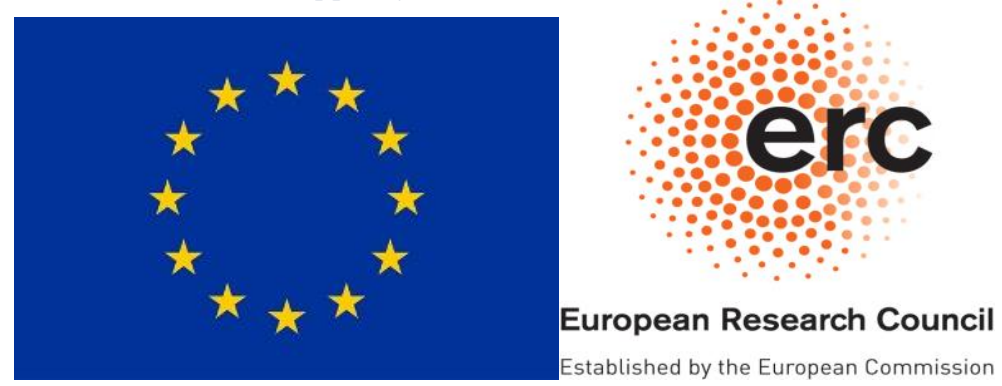


\section{ENTREPRENEURSHIP AND SUSTAINABILITY ISSUES}

ISSN 2345-0282 (online) http://jssidoi.org/jesi/ 2020 Volume 8 Number 2 (December) http://doi.org/10.9770/jesi.2020.8.2(9)

Mohamed Ramadan A. REZK

ORCID ID: https://orcid.org/0000-0002-7677-3072

Leonardo PICCINETTI

ORCID ID: https://orcid.org/0000-0002-7861-5668

Amr RADWAN

ORCID ID: https://orcid.org/0000-0002-5567-6708

Nahed M. SALEM

ORCID ID: https://orcid.org/0000-0003-3536-8502

Mahmoud M. Sakr

ORCID ID: https://orcid.org/0000-0001-9467-9250

Anas KHASAWNEH

ORCID ID: https://orcid.org/0000-0001-5693-2542

Make your research more visible, join the Twitter account of ENTREPRENEURSHIP AND SUSTAINABILITY ISSUES:

@Entrepr69728810

Copyright (C) 2020 by author(s) and VsI Entrepreneurship and Sustainability Center

This work is licensed under the Creative Commons Attribution International License (CC BY).

http://creativecommons.org/licenses/by/4.0/

(c) (†) Open Access 